\title{
List of sources
}

Kolchalovskaya N. Popugai s ploshadi Areco [Parrots from the Square of Arezzo].URL: https://www.litmir.me/br/?b=232160\&p=1

Schmitt E.-E. Les perroquets de la place d'Arezzo. Paris, 2013.

\section{АНАЛОГИИ В СЮЖЕТНЫХ МОТИВАХ ЯКУТСКОГО ОЛОНХО И ХАКАССКОГО АЛЫПТЫХ НЫМАХ ${ }^{1}$}

\section{А.Ф. Корякина}

Ключевые слова: эпос, олонхо, алыптых нымах, сравнительный анализ, сюжетные мотивы, девушки-богатырки. Keywords: epic, olonkho, alyptykh nymah, comparative analysis, plot motifs, girl-heroes.

\section{DOI 10.14258/filichel(2019)3-11}

Сравнительное изучение эпических традиций тюрко-монгольских народов с давних времен привлекало внимание фольклористов, фундаментальные исследования которых доказывают присутствие взаимосвязей в жанре, тематике, сюжетно-композиционной и образной системе, стиле изложения, в поэтическом языке эпосов генетически родственных народов.

В статье ведется сравнительно-типологическое исследование древних сюжетных мотивов якутского олонхо и хакасского алыптых нымах. Актуальность сравнительно-типологического сравнения была указана Б.Н. Путиловым: «<..> историческое изучение фольклора $<\ldots>$ невозможно без самого широкого и систематического сравнительного анализа, $<\ldots>$ без выявления и изучения фактов повторяемости, в конечном счете - без установления общих закономерностей и общих особенностей» [Путилов, 1976, с. 3]. Принимая утверждение крупного ученого за основу своего исследования, мы ставим цель - выявление сходств и особенностей мотивов якутского олонхо и хакасского алыптых нымах.

\footnotetext{
${ }^{1}$ Исследование выполнено при финансовой поддержке НИП СВФУ «Героические эпосы тюрко-монгольских народов Евразии: проблемы и перспективы сравнительного изучения» (2018-2021).
} 
Сравнительное изучение эпических традиций разных народов, как обязательная и важная часть историко-фольклорного анализа в современной фольклористике, может привести к выявлению родственных истоков эпических традиций и в дальнейших исследованиях - к раскрытию приобретенных в территориально самостоятельном развитии особенностей эпического творчества каждого отдельно взятого народа. В этом мы видим актуальность нашего исследования.

В анализе использованы сравнительно-сопоставительный и структуральный методы. Сравнительным материалом взяты тексты героических эпосов «Девушка-богатырь Джырыбына Джырылыатта» (Ядрихинский-Бэдьээлэ, 2011) ${ }^{1}$, записанного П.Н. Дмитриевым в 1970 году со слов сказителя П.П. Ядрихинского, и «Ай-Хуучин» (Хакасский героический эпос..., 1997) по записи В.Е. Майногашевой со слов П.В. Курбижекова в 1964 году. Основной единицей исследования выбран мотив как сюжетообразующий элемент. Для нас важно было определение Б.Н. Путилова: «Современное исследование фольклорных сюжетов (в особенности эпических) основывается, как правило, на признании того, что путь к пониманию сюжета, произведения в целом лежит через самое детальное рассмотрение составляющих его мотивов» [Путилов, 1997]. В эпосах сопоставлены древнейшие мотивы из составленного Е.Н. Кузьминой указателя типических мест эпосов тюрко-монгольских народов Сибири [Кузьмина, 2005].

Теоретической основой исследования послужили фундаментальные труды В.Я. Проппа о природе фольклорной общности [Пропп, 1946], В.М. Жирмунского по сравнительноисторическому изучению народного героического эпоса [Жирмунский, 1974], Е.М. Мелетинского о древнейшем типе героя в эпосе тюркомонгольских народов Сибири [Мелетинский, 1963], Б.Н. Путилова по типологии и этнической специфике эпического сказительства [Путилов, 1997] и др., работы хакасских фольклористов В.Е. Майногашевой [Майногашева, 1997, 2015], Н.С. Чистобаевой [Чистобаева, 2015], Ю.И. Чаптыковой [Чаптыкова, 2015] по сравнительному изучению хакасского национального эпоса с другими эпосами; якутских ученых И.В. Пухова [Пухов, 2004], А.П. Окладникова [Окладников, 2013], Г.У. Эргиса [Эргис, 1974], Н.В. Емельянова [Емельянов, 1980], В.В. Илларионова [Орто Халыма

\footnotetext{
1 Здесь и далее в круглых скобках даны ссылки на тексты из списка источников, приведенного в конце статьи.
} 
олонхолоро, 2016], А.Н. Даниловой [Данилова, 2016], Н.В. Павловой, [Павлова, 2012] М.Т. Гоголевой [Гоголева, 2015], Ю.П. Борисова [Борисов, 2015], С.Д. Львовой, Л.Н. Герасимовой [Gerasimova, Lvova, 2018], в которых рассматривались вопросы сравнительного изучения якутского эпоса.

Крупный якутский фольклорист И.В. Пухов первым из якутских фольклористов обнаружил сходство героических эпосов якутского и алтае-саянских народов. Он рассматривает типологическое сходство отдельных деталей, эпизодов, сюжетов древних эпосов как результат сходного творческого поиска в сходных жизненных условиях. Воспроизводя сравнение якутского олонхо с хакасскими эпосами, ученый выявил сходство в мотиве героического сватовства богатырей, в их защитительных функциях, в мотиве свадебного пира [Пухов, 1975].

Н.В. Емельянов, осуществивший систематизированный свод изложений сюжетов якутских олонхо, классифицировал олонхо о женщинах-богатырках как ранний тип сюжетосложения [Емельянов, 1980].

А.П. Окладников сходство олонхо с наиболее древними мотивами эпоса степных племен южной Сибири, Средней и Центральной Азии объяснил его сравнительно малой подверженностью изменениям [Окладников, 2013].

Исследования по сравнительному изучению типологического сходства якутского и хакасского эпосов корифеями-исследователями продолжают фольклористы современного эпосоведения.

А.Н. Данилова находит общность в якутском и хакасском эпосах в мотиве оборотничества девок-богатырок [Данилова, 2016]. Н.В. Павлова считает схожими тематику, мотив поэтизированного родства богатырей с лошадьми, мотива культа коня [Павлова, 2012]. М.Т. Гоголева отметила совпадения в ономастике и в наиболее древних общетюркских пластах некоторых лексических единиц [Гоголева, 2015].

Ю.П. Борисов в текстах эпосов «Могучий Эр Соготох» и «АйХуучин» обнаружил совпадения в способах образования ритмикосинтаксических параллелизмов (дословное повторение, подбор вариантных и контекстных синонимов, аналитического противопоставления), в структурном оформлении и семантической нагрузке параллелизмов [Борисов, 2015]. Сопоставив языковые особенности текстов «Кыыс Дэбилийэ» и «Ай Хуучин», С.Д. Львова и Л.Н. Герасимова выявили сходства и различия в выражении сравнений, образов и объектов сравнений [Gerasimova, Lvova, 2018]. 
Известный хакасский ученый-фольклорист В.Е. Майногашева нашла общность в таких мотивах алыптых нымах и олонхо, как похищение врагом сестры, жены, коня; измена старшей сестры богатыря; способность оборотничества. Она утверждает, что данные мотивы уходят «в общую древнюю традицию тюркоязычных племен, о которой свидетельствует наличие в эпосе тюркоязычных народов Сибири мотива происхождения героя от лошади» [Майногашева, 1997, c. 10].

Хакасские исследователи Н.С. Чистобаева [Чистобаева, 2015], Ю.И. Чаптыкова [Чаптыкова, 2015] в своих работах рассмотрели традиционные эпические мотивы в хакасском национальном героическом эпосе.

Как видно из краткого изложения литературы по сравнительному изучению эпических традиций якутского и хакасского народов, проблема больше изучена якутскими специалистами. Основу изучения олонхо в контексте эпосов тюркоязычных народов Сибири: алтайцев, шорцев, хакасов и бурят заложил И.В. Пухов. Проведенные в дальнейшем исследования касаются только отдельных вопросов по сравнительному изучению древних мотивов. В данной статье впервые предпринимается попытка более целостного изучения аналогий древних мотивов, что является новизной исследования.

По объему, охвату жизненных коллизий, культурно-эстетической значимости олонхо и алыптых нымах являются самыми крупными жанрами устного народного творчества. Сказания о защитницах своих сородичей от иноземных завоевателей и чудовищ были широко распространены среди тюрко-монгольских народов. Большинство из них считаются исследователями наиболее ранними эпосами.

В героических сказаниях «Джырыбына Джырылыатта» и «АйХуучин» воспеваются могучие, непобедимые защитницывоительницы. По объему эти сказания почти равны: олонхо «Девушкабогатырь Джырыбына Джырылыатта» П.П. Ядрихинского состоит из 8210 поэтических строк, «Ай-Хуучин» - из 8059 стихотворных строк.

В сюжетах наблюдается разница. Олонхо содержит две сюжетные линии. В первой сюжетной линии Джырыбына Джырылыатта в сражении с представителем племени абаасы - чудовищем спасает родного брата - богатыря Тойон Джёллююта. В данной сюжетной линии Джырыбына Джырылыатта - защитник племени айыы. Вторая сюжетная линия следует за героическим сватовством богатырей трех миров олонхо к Джырыбына Джырылыатта. Здесь ее назначение - «род саха продолжить, с очагом священным, мир живой плодить» (Ядрихинский-Бэдьээлэ, 2011, с. 434). 
В отличие от якутского эпоса в хакасском эпосе ведется повествование о трех поколениях богатырей-воинов наследственного чурта-владений. Хакасские исследователи считают, что в основу данного эпоса легли ранее самостоятельно бытовавшие и бытующие мифологические и легендарно-эпические сюжеты: о деве-богатырке Алып-Хыс-Хан; о богатыре Хан-Миргене и о деве-богатырке дочери коней-скакунов Ай-Хуучин, у которой брат-близнец становится ей верным конем.

Время первотворения мира. В 40-строчном зачине якутского эпоса описывается время первотворения Среднего мира, формульными словами указывается «эпическое» время, идентичное с пространственно-временным фоном эпических сказаний тюркомонгольских народов Сибири: «Далеко за вершинами / Древних лет тревожных, / Давно за хребтами /Стародавних дней бранных <...> Когда три саха еще не появились/Пять саха еще не расселились <...> Красивая - нарядная, /Изначальная матерь земля / Назначена-сотворена была, говорят» (Ядрихинский-Бэдьээлэ, 2011, c. 13).

Зачин «Ай-Хуучин» состоит всего из восьми стихотворных строк, и события относятся к древности - эпохе, «когда находили медь»: «После того как впервые земля сотворилась, /Было время, когда находили куски красной меди,/A быстрые реки, рукавами разлившись, / По камням попрыгивая, текли» (Хакасский героический эпос..., 1997, с. 15).

Как в эпосах тюрко-монгольских народов, в зачине сопоставляемых эпосов время первотворения мира описано как мифическая эпоха первотворения, как заря мироздания.

Владения богатырей. В олонхо предстают три мира, из них Средний мир - место обитания человеческого племени. Это прекраснейшая картина мира с изобильными пастбищами для скота и охотничьими угодьями, пронизанная мотивами древней мифической космогонии: «Почвой плодородной покрытая,/Дерном краснымм позолоченная/C пастбищами из трав зеленых,/C узорами причудливыми /Из ияветов прекрасных, / Бесконечно многоцветная, /Животными и людьми /Безмерно много заселенная / Создана-сотворена стоит» (Ядрихинский-Бэдьээлэ, 2011, c. 15). В этой чудесной земле: «Скота рогатого / Уйма завелась, / Скакунов быстроногих / Множество родилось, / C богатством несметным, / Живности множеством, /Богатьх людей житье, оказалось» (Ядрихинский-Бэдьээлэ, 2011, с. 55). 
Земля богатырей в «Ай-Хуучине» также красива и богата, как в якутском эпосе: «На берегу [великой реки] Ханылм-талай/Люд-народ живет /C передней стороны красивого аала/Ханым-сын, высочайший из хребтов, [стоит,] / В быструю [великую реку] Ханымталай/Он, раздвоившись, уткнулся/Там, где он подступает $\kappa$ великой реке, /Есть девятигранная [скала] Хызыл-хайа, /C другой стороны [хребта] Ханым-сын/Песчаная степь раскинулась, /По широкой песчаной степи/Выпасной скот разбрелся./Обильно расплодившийся многочисленный скот / В большой степи, похоже, не умещается» [Хакасский героический эпос..., 1997, с. 63]. Для героев алыптых нымах родина - это чурт, что воспроизводится как центр мироздания. Через этот чурт герой связан со всем миром солнечной земли, под которой подразумевается древняя, средневековая и нового времени Хакасия с населявшими ее народами и племенами.

В этом мотиве перекликается представление якутского и хакасского народов об идеальном мире: идеальная жизнь на солнечной земле - это непременно вольготно пасущиеся на земле богатырей несметные стада скота и табунов лошадей. В этом заключается понятие о счастливой жизни народов-скотоводов.

Чудесное рождение героинь. По В.М. Жирмунскому «мотив чудесного зачатия и рождения будущего героя имеет широкое распространение в мифе, сказке и эпосе» [Жирмунский, 1974, с. 223].

В олонхо «Джырыбына Джырылыатта» у восьмидесятилетнего старика Арылы Тойон и старухи Кэрэмэс Хотун родились мальчик Тойон Джеллюют, будущий богатырь, и девочка, о которой роды принимавшая Айыы Нуоралджын сказала: «Приветливая Иэйиэхсит хотун из девочек отборную-остистую, / В улусе солнечном / Самую сильную / Тебе сотворила-подарила» (Ядрихинский-Бэдьээлэ, 2011, с. 87). Дети вырастают необыкновенно быстро: «На третий день / Как трехлетние стали,/На пятый день/Как пятилетние/Довольно окрепли» (Ядрихинский-Бэдьээлэ, 2011, с. 89).

В хакасском эпосе будущая богатырка Ай-Хуучин появляется на свет в конском табуне от породистых скакунов аран чула am, принадлежащих ханше-правительнице народа этого чурта - девебогатырке по имени Хыс Хан. Вместе с будущей девой-богатыркой рождается и ее будущий конь - брат-близнец (Хакасский героический эпос..., 1997).

Эпосы сближает мотив чудесного рождения героинь-богатырок.

Мотив наречения богатырок. Героиню олонхо нарекли именем «С желто-белого неба наяву спущенным, Словами говорящим $c$ молочно-бельмм конем Джырыбына Джырыльатта» (Ядрихинский- 
Бэдьээлэ, 2011, с. 89). Девочку Ай Хуучин нарекает страшноликая Хыс-Хан: «Конями рожденная Ай-Хуучин, Которая ездит на девятисаженном Треухом Пего-саврасом коне - твое имя-прозвище» (Хакасский героический эпос..., 1997).

Имена обеих богатырок отражают их происхождение, назначение. Они - воины-защитники соплеменников, с предназначенными свыше конями.

Главная функция богатырок. Стержневой идеей олонхо «Богатырка Джырыбына Джырылыатта» является защита племен айыы, жителей Среднего мира, от нападений чудовищ, племен Нижнего мира, а в конце олонхо она становится верной женой, видящей свое назначение в продолжении рода айыы. В сказании «АйХуучин» отказываются от семейной жизни и обеспечивают благополучную жизнь соплеменников в чурте.

Внешний облик богатырок. Главным достоинством эпического богатыря является внешняя красота и физическая мощь. Богатыри отличаются не только атлетическим видом, непомерной силой и прытким нравом, но и необыкновенной красотой. В описании величавой красоты богатыря не отходит от традиции и П.П. Ядрихинский. Описывая божественную красоту богатырки, олонхосут создает образ сказочно красивой девушки айыы: «Подобно лучам/Летней зари/С лицом светльм, /Словно девять светил сочлись/С видом лучезарным, /Словно три солнца соединились» (Ядрихинский-Бэдьээлэ, 2011, с. 153).

В хакасском эпосе отсутствует развернутый портрет богатырки Ай-Хуучин: ее внешняя красота передается прилагательными «могучая», «прекрасная», «достойнейшая».

В описании красоты девушек-богатырок кроется мечта народов об идеальном герое-защитнике.

Мотив выезда богатыря. Типическое место, характеризующее мотив выезда богатыря из дома, является важным в сюжетном строе в архаическом эпосе, оно является завязкой конфликта олонхо. Поводом к выезду богатыря из дома в тюрко-монгольских эпосах становятся осмотр владений, пересчет скота, выезд на охоту, весть о похищении соплеменников богатыря представителями других племен и т.д. [Кузьмина, 2005]. В якутских олонхо часто с такими вестями приезжают посыльный Сорук Боллур, богатырский конь, богатырь в облике птицы и т.д. В первой сюжетной линии олонхо «Джырыбына Джырылыатта» прибывает посыльный Сорук Боллур, который передает богатырю Тойон Джёллююту просьбу родителей красавицы Сыралыма Куо спасти их дочь от плена богатыря абаасы Тимир 
Чохчордоона. Во второй линии весточка приходит с конем богатыря Тойон Джеллююта. Прибытие коня без хозяина свидетельствует о случившейся беде, которая постигла Тойон Джёллююта. Джырыбына Джырылыатта немедля собирается в героический поход.

В «Ай-Хуучин» обнаруживаются мотив похищения: только что родившихся в отсутствие Хан Миргена его детей - близнецов похищают демонические женщины и увозят в подземный мир. Хан Мирген едет по их следам и проникает в подземный мир. Здесь злодей превращает Хан Миргена в черную собаку. Ай-Хуучин, спеша на помощь, спускается в подземное царство. Она уничтожает демонических врагов, спасает Хан Миргена и его детей, и с ними возвращается на родину.

В обоих эпосах присутствуют древние мотивы выезда богатыря в поход.

Борьба богатырок с чудовищами. Кульминацией якутского олонхо является сражение богатыря айыы с чудовищем-абаасы. Ход схватки между богатырями айыы и чудовищами описывается с особым пристрастием. Здесь художественно рисуются: место действия (это могут быть средний, нижний миры, склон горы и т.д.); продолжительность сражения, которое может длиться годами; физические увечья, которые богатыри наносят друг другу во время схватки; последствия их схватки для окружающей среды; степень накала борьбы; зов на помощь; прибытие и помощь шаманок, братьев богатырей, поражение и гибель одного из богатырей, окончательная расправа с противником и т.д. В олонхо: «Землю талую/До бедренного сустава/В прах истоптали, / Землю мерзлую / До чамек коленных / Насквозь продавили». Страшными для жителей среднего мира оказались последствия борьбы: «Звезда-сындылыс (быстрая) загорелась,/Гром страшный загремел./Землю с поперечными пятнами /Словно воду в сосуде-тордуйа расплескали, / Мир срединный /Как воду в лукошке-атыйах / Берестяном всколыхнули» (Ядрихинский-Бэдьээлэ, 2011).

В «Ай-Хуучин» наблюдается присутствие подобного описания продолжительности боя: «Семь дней борясь [противники] / Победить друг друга не могут./Когда девять дней миновало,/Могучая Ай Хуучин/Ребром ребро придавила/Альип Хусхуну» (Хакасский героический эпос..., 1997, с. 271). Также передается накал сражения: «Гористое место растаптывая, / Два богатыря бьются, / Холмистые места два богатыря,/Разрушая, топчут./Будто бы не расходившийся бельий туман / Стал клубиться, / Не поднимавшийся 
синий туман / Во все стороны стал расползаться» [Хакасский героический эпос..., 1997, с. 271].

В мотивах жестоких сражений богатырок с чудовищами наблюдается схожесть.

Сила богатырок. Как богатырь девушка-воительница в якутском олонхо не имеет равных. В борьбе с богатырями абаасы раскрываются ее подлинные богатырские черты - физическая сила, ловкость в движениях, меткость глаз: «У девушки-богатыря/Джырыбына Джырыльатта /Удары сильнее стали, /Пинки вернее стали /Противника мерзкого / Семислойный толстый,/ Тяжельй паниирь железный / Ударами-пинками /Долбить-крошить стала» (Ядрихинский-Бэдьээлэ, 2011, с. 235).

По физической силе Ай-Хуучин не уступает богатыряммужчинам: «Под яснымм небом/Не родится богатырь, / Равный АйХуучин» (Хакасский героический эпос..., 1997, с. 175). «Могучая достойнейтая из дев,/Побороть себя не давая, с ним схватилась./Хватающие руки Ай-Хуучин/Крепкому капкану были подобны, /Две руки, ее хватающие/Железным клещзам, были подобныл» [Хакасский героический эпос..., 1997, с. 271].

$\mathrm{B}$ способах описания физической силы богатырей присутствует очевидное соответствие.

Мотив оборотничества. Богатыри способны создавать чудеса, Джырыбына Джырылыатта - не исключение. Она использует свою способность к оборотничеству, чтобы попасть в Нижний мир: «Громко вскрикнув/C восемью гранями /B жердь серебряную ютюмэх / Сразу оборотившись / В дыру узкую/Птиией-бекас заголосив, /Промелькнула исчезла» (Ядрихинский-Бэдьээлэ, 2011, c. 249).

Ай-Хуучин еще девочкой имеет способность превратиться в сокола, в образе которого она помогает Хан-Миргену в героическом сватовстве к Алып-Хан-Хыс и уничтожает всех, кто входит в демоническое царство.

Мотив оборотничества в эпосах связан с древними мотивами.

Мотив расправы над трупом побежденного врага. Одним из древних мотивов является мотив жестокой расправы богатыря над трупом побежденного врага: «Девушка-богатырь / Сына абаасы/Ногой в подошвах золотых /На аорту - сис ёся/с силою наступив/Шеювместе с головой/Сердие-гльбу твердую, / С придатком печень черную/Вместе все вырвав/На пику грозную насадив / Высоко над головой подняла» (Ядрихинский-Бэдьээлэ, 2011, c. 239). «Могучая Ай-Хуучин/Тело достойного богатыря 
схватив, / Труп Красно-каурого коня схватив, / Вместе-вкупе их схватив, / Шесть-семь раз раскачав, / На плечи свои подняла, / И через скалу бросила,/В реку Ханьл-талай/В самую глубь низвергла» (Хакасский героический эпос..., 1997, с. 176).

В данном мотиве оба сказителя придерживаются древних канонов.

Конь-вестник. По традиции эпоса, кони - верные друзья своим хозяевам. Происхождение богатырского коня - разное: кони бывают ниспосланными свыше, дарованными, выкованными кузнецами и т.д. Часто они становятся спасателями. В якутском олонхо Джырыбына Джырылыатта узнает о беде, случившейся с братом Тойон Джёллюютом, по тому, что его конь возвращается без седока, и немедля собирается в боевой поход для его спасения. И кони АйХуучин и Алтын-Арыг прибегают в чурт и оповещают о беде своих богатырок-хозяек. В описании происхождения, внешнего вида, снаряжения, езды, чудес богатырского коня, способствующих созданию образа главного героя, выражается искренняя любовь коневодческих народов к этому животному. По словесному портрету они - необыкновенно красивы, сильны, обладают чудесными способностями. А богатырский бег коня - неисчерпаемый источник для поэтических художественных приемов в олонхо: метафор, эпитетов, сравнений, гипербол. В якутском олонхо и хакасском алыптах-нымахе в описании красоты, силы, ловкости коня представлены такие чувства народа, как любовь, восхищение, благодарность.

Мотив помощи родственников. Связывает якутский эпос с хакасским эпосом отражаемый в них обоих мотив семьи, родственных связей. «В эпосе показаны близкородственные взаимоотношения, забота друг о друге семьи и рода», - пишет о хакасском эпосе Н.С. Чистобаева [Чистобаева, 2015, с. 130]. Так же можно сказать и о якутском олонхо. Богатырка Джырыбына Джырылыатта спасает брата, попавшего в злодейские чары девушки абаасы. Когда Ай-Хуучин терпит поражение в сражении с чудовищами, на помощь к богатырке едут племянники - Алтын-Теек и Алтын-Иргек. В другом сюжете иссякнувшие силы Ай-Хуучин возрождает Ай-Чарых-Хыс, дочь ХанМиргена, прилетевшая в образе ласточки.

Описание чудовищ-врагов. Обязательным элементом в развитии действия олонхо является характеристика чудовищ, абаасы, образующая контраст с портретом людей айыы. Враждебный мир Джырыбына Джырылыатта составляют представители Нижнего мира богатыри абаасы Тимир Чохчордоон, Хахсаат Буурай. Описание 
внешности абаасы Тимир Чохчордоон в «Джырыбына Джырылыатта» не отличается от описаний в текстах дошедших до нас древних олонхо: с ногой «подобно пню гнилому», с одной рукой «как клещуи кузнечные», а лицо «с губами вывернутылми/Подобно проруби промерзшей / Со зльмми глазами красными, /Подобно кочке травяной, / С сопящчим носом мясистым, /Подобно горке с трещчиной, / С открытылм как рытвина ртом, /C щеками со ржавчиной» (Ядрихинский-Бэдьээлэ, 2011 , с. 219). Также страшны, уродливы в эпосе хакасов айна - злые демонические существа подземного мира: «Жутко страшное существо: / Между глазами три верика, / С толстенным носом / С безобразным корявым лиц̧ом» (Хакасский героический эпос..., 1997, c. 251).

Описания противников богатырей в эпосах разных народов в зависимости исторического времени создания эпического произведения различны. В древних эпических текстах это могут быть однорукие и одноногие чудовища с одним глазом посередине лба, парни-оборотни, железноклювые вороны, комары-великаны, огромные змеи, бешеные волки или же страшные существа с несколькими головами, обладающие огромной силой и живучестью. В рассматриваемых эпосах наблюдается идентичность данного мотива.

Возвращение мирной, счастливой жизни. В развязке обоих эпосов в солнечной стране устанавливается мирная, счастливая жизнь. В олонхо богатыри айыы Джырыбына Джырылыатта и Ала Дуурай «к алаасу своему по дороге благословенной направились». Они стали жить счастливо, «род уранхайцев продлевая, рождаясь-умножаясь» (Ядрихинский-Бэдьээлэ, 2011, с. 435). В алыптых-нымахе родственники Ай-Хуучин «нескончаемую еду они имели, / Держали дом с высоким тюнюком, / Неиссякаемую силу они имели, / Родных и близких признавая, жили» (Хакасский героический эпос..., 1997, c. 423).

Таким образом, сравнительное изучение сюжетных мотивов якутского и хакасского эпосов на материале олонхо «Девушкабогатырь Джырыбына Джырылыатта» и алыптых нымах «Ай-Хуучин» показало присутствие аналогий в сюжетных мотивах времени первотворения мира, владений богатырей, чудесного рождения героинь, наречения богатырок, главной функции богатырок, красоты богатырки, выезда богатыря, описания борьбы богатырок с чудовищами, физической силы богатырок, оборотничества, жестокой расправы над трупом побежденного врага, коня-вестника, помощи родственников, описания чудовищ-врагов, установления мирной жизни. Эти мотивы являются общими, каноническими для архаических 
эпосов тюрко-монгольских народов о воинствующих девушкахбогатырках. Зародившись когда-то в эпическом творчестве древних предков тюрко-монгольских народов, эти древние сказания передавались и распространялись с соблюдением исконных эпических канонов. Так они получили продолжение у якутских олонхосутов и хакасских хайджи-нымахчи. П.П. Ядрихинский-Бэдьээлэ и П.В. Курбижеков являются продолжателями эпической традиции тюрко-монгольского сказительства.

Анализ показывает, что сходство якутского и хакасского эпосов больше наблюдается в мотивах, эпизодах, а не в целом, объяснение чему мы находим у И.В. Пухова: «Со времени совместной жизни якутов с алтае-саянскими народами миновало много времени, эпическое творчество их прошло большой путь, развиваясь самостоятельно» [Пухов, 2004, с. 160].

При присутствии аналогий наблюдаются и отличия в сюжетных мотивах: к примеру, в хакасском эпосе отсутствуют обязательные для якутского эпоса архаичные мифологические образы духовпокровительниц семьи и детей Иэйиэхсит хотун и Айыысыт хотун, духа-хозяйки Среднего мира Аан Алахчын Хотун, духа огня Хатан Тэмерийэ, священного дерева Аал Кудук Мас. В отличиях мотивов мы видим подтверждение вывода хакасского исследователя В.Е. Майногашевой: «Отдалившись территориально друг от друга, они [тюрко-монгольские народы] прервали и тесные фольклорные связи. В результате эпическая культура каждого народа стала развиваться посвоему» [Майногашева, 1997, с. 20].

Сравнительно-типологическое изучение сходств и отличий эпосов тюрко-монгольских народов требует дальнейших обширных исследований специалистов.

\section{Литература}

Борисов Ю.П. Особенности параллелизма в якутском олонхо «Модун Эр Соқотох» В.О. Каратаева и хакасском эпосе «Ай-Хуучин» П.В. Курбижекова. // Сравнительное изучение тюрко-монгольских эпосов. Якутск, 2015.

Гоголева М.Т. Олонхо и хакасский героический эпос «Ай-Хуучин» // Филологические науки: вопросы теории и практики. № 1 (43): в 2-х ч. Ч. II. 2015.

Данилова А.Н. Чудесное рождение богатырки как архаический мотив в якутских олонхо о женщинах-богатырках // Филологические науки. Вопросы теории и практики. 2016. № 11 (65). Ч. 3.

Емельянов Н.В. Сюжеты якутских олонхо. М., 1980.

Жирмунский В.М. Тюркский героический эпос. Л., 1974.

Кузьмина Е.Н. Указатель типических мест героического эпоса народов Сибири (алтайцев, бурят, тувинцев, хакасов, шорцев, якутов). Новосибирск, 2005. 
Майногашева В.Е. О хакасском героическом эпосе и алыптых нымахе «АйХуучин» // Памятники фольклора народов Сибири и Дальнего Востока. Новосибирск, 1997. Т. 16.

Майногашева В.Е. Хакасский героический эпос Алыптых нымах: поиски исторических реалий и периодизация (избранные труды). Абакан, 2015.

Мелетинский Е.М. Происхождение героического эпоса: ранние формы и архаические памятники. М., 1963.

Окладников А.П. Якутский эпос (олонхо) и его связь с югом. Якутск, 2013.

Орто Халыма олонхолоро / В.В. Илларионов, Т.В. Илларионова. Дьокуускай, 2016. (Саха боотурдара: в 21 тт.; Т. 18) (на якут. языке).

Павлова Н.В. Сюжетно-тематическое содержание олонхо и алыптых нымаха (сравнительный анализ якутского и хакасского героических эпосов) // Якутский героический эпос олонхо: вопросы научного изучения. Якутск, 2012.

Пропп В.Я. Специфика фольклора // Труды юбилейной научной сессии Ленингр. ун-та. Секция филол. наук. Л., 1946.

Путилов Б.Н. Методология сравнительно-исторического изучения фольклора. Л., 1976.

Путилов Б.Н. Эпическое сказительство: Типология и этническая специфика. М., 1997.

Пухов И.В. Героический эпос тюрко-монгольских народов Сибири: общность, сходства, различия // Типология народного эпоса. М., 1975.

Пухов И.В. Героический эпос алтае-саянских народов и якутское олонхо. Якутск, 2004.

Саввинова Г.Е. Фольклорно-этнографические экспедиции по исследованию эпического наследия Республики Саха (Якутия). Филология и человек. 2018. № 2. DOI: 10.14258/filichel(2018)2-17

Чаптыкова Ю.И. Древнейшие мотивы в героическом эпосе «Белый жеребенок и сивый жеребенок» // Сравнительное изучение тюрко-монгольских эпосов. Якутск, 2015.

Чистобаева Н.С. Традиционные эпические мотивы в героическом эпосе хакасов // Сравнительное изучение тюрко-монгольских эпосов. Якутск, 2015.

Эргис Г.У. Очерки по якутскому фольклору. М., 1974.

Gerasimova L.N., Lvova S.D. Structural and Functional Features of Comparison Methods in the Yakut and Khakass Epics // Journal of History Culture and Art Research. 2018. Vol. 7. No. 3. DOI: 10.7596/taksad.v7i3.1721

\section{Список источников}

Хакасский героический эпос «Ай-Хуучин» // Памятники фольклора народов Сибири и Дальнего Востока. Новосибирск, 1997. Т. 16.

Ядрихинский-Бэдьээлэ П.П. Девушка-богатырь Джырыбына Джырылыатта / запись со слов олонхосута П.Н. Дмитриева-Туутук. Якутск, 2011.

\section{References}

Borisov Iu.P. Osobennosti parallelizma v iakutskom olonkho «Modun Er So5otokh» V.O. Karataeva i khakasskom epose "Ai- Khuuchin» P.V. Kurbizhekova [The Specifics of Parallism in V.O. Karataev's Yakut Olonkho «Modun Er Soghotokh» and P.V Kurbizhekova's Khakass epos «Ai-Khuuchin»]. Sravnitel'noe izuchenie tiurko-mongol'skikh eposov [Comparative Study of Turko-Mongolian Eposes]. Iakutsk, 2015.

Gogoleva M.T. Olonkho i khakasskii geroicheskii epos "Ai-Khuuchin»[Olonkho and the Khakass Heroic Epic «Ai-Khuuchin»]. Filologicheskie nauki: voprosy teorii $i$ praktiki 
[Philogical Science: Questions of Theory and Practice]. No. 1 (43): in 2 pt. Pt. II. Tambov, 2015.

Danilova A.N. Chudesnoe rozhdenie bogatyrki kak arkhaicheskii motiv v iakutskikh olonkho o zhenshchinakh-bogatyrkakh [The Miraculous Birth of Female Warriors as an Archaic Motif in Yakut Olonkho about Women-Warriors]. Filologicheskie nauki. Voprosy teorii i praktiki [Philogical Science: Questions of Theory and Practice]. Tambov, 2016. No. 11 (65). Pt. 3.

Emel'ianov N.V. Siuzhety iakutskikh olonkho [Plots of Yakut Olonkho]. Moskva, 1980. Zhirmunskii V.M. Tiurkskii geroicheskii epos [The Turkic Heroic Epos]. Leningrad, 1974.

Kuz'mina E.N. Ukazatel' tipicheskikh mest geroicheskogo eposa narodov Sibiri (altaitsev, buriat, tuvintsev, khakasov, shortsev, iakutov) [Index of Typical Locations in the Heroic Epics of Siberian Peoples (Altai, Buryat, Khakass, Short, Yakut)]. Novosibirsk, 2005.

Mainogasheva V.E. O khakasskom geroicheskom epose $i$ alyptykh nymakh "AiKhuuchin» [The Khakass Heroic Epic and Alyptykh Nymakh]. Pamiatniki fol'klora narodov Sibiri i Dal'nego Vostoka [Folkloric Monuments of the Peoples of Siberia and the Far East]. Novosibirsk, 1997. Vol. 16.

Mainogasheva V.E. Khakasskii geroicheskii epos Alyptykh nymakh: poiski istoricheskikh realii $i$ periodizatsiia (izbrannye trudy) [The Khakass Heroic Epic Alyptykh Nymakh: Serach for Historic Realia and Periodization (selected works). Abakan, 2015.

Meletinskii E.M. Proiskhozhdenie geroicheskogo eposa: rannie formy i arkhaicheskie pamiatniki [Origin the Heroic Epos, Early Forms and Archaic Monuments]. Moskva, 1963.

Okladnikov A.P. Iakutskii epos (olonkho) $i$ ego sviaz' $s$ iugom [The Yakut Epos (olonkho) and Its Connection with the South]. Iakutsk, 2013.

Orto Khalyma olorkholoro / V.V. Illarionov, T.V. Illarionova. D'okuuskai, 2016. (Sakha booturdara: in 21 vols. Vol. 18. (na iakut. iazyke).

Pavlova N.V. Siuzhetno-tematicheskoe soderzhanie olonkho $i$ alyptykh nymakha (sravnitel'nyi analiz iakutskogo i khakasskogo geroicheskikh eposov) [The Plot-Based Thematic Contents of Olonkho and Alyptykh Nymakh (a comparative analysis of Yakut and Khakass heroic epics)]. Iakutskii geroicheskii epos olonkho: voprosy nauchnogo izucheniia [Yakut Heroic Epos Olonkho: Questions of Scientific Study]. Iakutsk, 2012.

Propp V.Ia. Spetsifika fol'klora [The Specifics of Folklore]. Trudi iubileinoi nauchnoi sessii Leningr. un-t. Sektsiia filol. nauk [Proceedings of the Anniversary Scientific Session of Leningrad University. Section of Philological Science]. Leningrad, 1946.

Putilov B.N. Metodologiia sravnitel'no-istoricheskogo izucheniia fol'klora [Methodology of the Comparative-Historic Study of Folklore]. Leningrad, 1976.

Putilov B.N. Epicheskoe skazitel'stvo: Tipologiia $i$ etnicheskaia spetsifika [Epic Storytelling: Typology and Ethnic Specificity]. Moskva, 1997.

Pukhov I.V. Geroicheskii epos tiurko-mongol'skikh narodov Sibiri: obshchnost', skhodstva, razlichiia [The Heroic Epos of the Turkic-Mongolian Peoples of Siberia: Commonalities, Similarities, Differences]. Tipologiia narodnogo eposa [Typology of the National Epic]. Moskva, 1975.

Pukhov I.V. Geroicheskii epos altae-saianskikh narodov $i$ iakutskoe olonkho [The Heroic Epos of the Altaic-Saian Peoples and Yakut Olonkho]. Iakutsk, 2004.

Savvinova G.E. Phol'klorno-etnographicheskie ekspedicii po issledovaniyu epicheskogo naslediya Respubliki Saha (Yakutia) [Folklore-Etnographic Expeditoins to Study the Epic Heritage of the Republic of Sakha (Yakutia)]. Filologiya I chelovek [Philology \& Human]. 2018. No. 2. DOI: 10.14258/filichel(2018)2-17

Chaptykova Iu.I. Drevneishie motivy v geroicheskom epose «Belyi zherebenok $i$ sivyi zherebenok» [Ancient Motifs in the Heroic Epic «Belyi Zherebenok I Sivyi Zherebenok»]. Sravnitel'noe izuchenie tiurko-mongol'skikh eposov [Comparative Study of Turko-Mongolian Eposes]. Iakutsk, 2015. 
Chistobaeva N.S. Traditsionnye epicheskie motivy $v$ geroicheskom epose khakasov [Traditional Epic Motifs in Khakass Heroic Epics]. Sravnitel'noe izuchenie tiurko-mongol'skikh eposov [Comparative Study of Turko-Mongolian Epose]. Iakutsk, 2015.

Ergis G.U. Ocherki po iakutskomu fol'kloru [Essays on Yakut Folklore]. Moskva, 1974.

Gerasimova L.N., Lvova S.D. Structural and Functional Features of Comparison Methods in the Yakut and Khakass Epics. Journal of History Culture and Art Research, 2018. Vol. 7. No. 3. DOI: 10.7596/taksad.v7i3.1721

\section{List of sources}

Khakasskii geroicheskii epos «Ai-Khuuchin» [The Khakass Herioc Epic «AiKhuuchin»]. Pamiatniki fol'klora narodov Sibiri i Dal'nego Vostoka [Folkloric Monuments of the Peoples of Siberia and the Far East]. Novosibirsk, 1997. Vol. 16.

Iadrikhinskii-Bed'eele P.P. Devushka-bogatyr' Dzhyrybyna Dzhyrylyatta. Zapis' so slov olonkhosuta P.N. Dmitrieva-Tuutuk [Girl-Warrior Dzhyrbyna Dzhyrylyatta. Recording of an olonkhosut's words P.N. Dmitriev-Tuutuk]. Iakutsk, 2011. 